\title{
HISAB AWAL BULAN HIJRIYAH DALAM KITAB “AL-KHULASHOH AL-WAFIYAH"
}

\author{
Sayful Mujab \\ Fakultas Syariah IAIN Kudus \\ Email: qutbsayf@iainkudus.ac.id
}

\begin{abstract}
One of the methods developed and used as a reference by Indonesian Muslim scholars is the early reckoning of the Islamic month which is contained in the book al-Khulashoh alWafiyah. This article aims to examine how the initial hijriyah reckoning in al-Khulashoh al-Wafiyah. This study is included in the domain of literature review with a qualitative approach. The results of the study show that the hijriyah calendar that applies to Muslims is based on the position of the moon on the earth and sun. The movement of the moon to the earth is relatively constant every year, so that these data can be used as a reference for predicting the position of the moon on earth and the sun. The prediction of the height of the new moon becomes a reference in determining the hijriyah calendar.
\end{abstract}

Keywords: Reckoning, Hijriyah Calendar, Al-Khulashoh Al-Wafiyah.

\begin{abstract}
Abstrak
Salah satu metode yang berkembang dan dijadikan acuan oleh cendekiawan muslim Indonesia adalah hisab awal bulan hijriyah yang terdapat dalam kitab alKhulashoh al-Wafiyah. Artikel ini bertujuan mengkaji tentang bagaimana hisab awal hijriyah dalam al-Khulashoh al-Wafiyah. Kajian ini termasuk dalam ranah kajian kepustakaan dengan pendekatan kualitatif. Hasil kajian menunjukkan bahwa kalender hijriyah yang berlaku bagi umat Islam didasarkan kepada posisi bulan terhadap bumi dan matahari. Pergerakan bulan terhadap bumi relatif tetap pada setiap tahunnya, sehingga data-data tersebut dapat dijadikan sebagai acuan untuk prediksi posisi bulan terhadap bumi dan matahari. Prediksi ketinggian hilal ini menjadi acuan dalam penentuan kalender hijriyah.
\end{abstract}

Kata Kunci: Hisab, Kalender Hijriyah, al-Khulashoh al-Wafiyah

\section{PENDAHULUAN}

Pada awal abad ke-20 M, illmu falak sudah berkembang di Indonesia. Perkembangan tersebut dimulai ketika ulama yang belajar di Haramian membawa catatan-catatan ilmu falak yang telah mereka pelajari, kemudian mereka ajarkan kepada para santri (Khazin, 2005: 30). Beberapa penelitian yang sudah dilakukan berkaitan dengan penentuan kalender hijriyah sudah banyak. Diantaranya penelitian dengan judul Hisab Urfi Syekh Abbas Kutakarang: Kajian Etnoastronomi dalam Penentuan Awal Bulan Hijriah. Penelitian ini dilakukan oleh Hasna Tuddar Putri dengan metode penelitian kualitatif deskriptif. Hasilnya 
menyebutkan bahwa karya Syekh Abbas Kutakarang yang fenomenal adalah kitab Tāj al-Mulūk, di dalamnya terdapat konsep hisab urfi yang hampir sama dengan hisab aboge. Selama ini hisab urfi seperti aboge hanya dikenal di Jawa.

Faktanya, Syekh Abbas Kutakarang juga menggunakan hisab seperti sistem aboge tetapi dengan konsep yang berbeda. Hisab urfi Syekh Abbas Kutakarang unik dan berbeda dengan hisab aboge dalam penentuan awal bulan Hijriah. Ia menggunakan kaidah ilmu falak tidak hanya untuk keperluan ibadah, melainkan untuk menghitung hari baik dan buruk, untuk pertanian dan menghitung musim. Hisab urfi Syekh Abbas Kutakarang dalam kajian ilmu falak tergolong dalam kajian etnoastronomi yaitu kajian yang menghubungkan antara astronomi dan budaya dalam penggunaan kaidah falak.

Karya-karya ilmu falak kala itu pada umumnya menggunakan data-data astronomis yang bersumber dari Zaij Ulugh Beik al Samarqandi, yang sistem perhitungannya terbilang sederhana, masih menggunakan perhitungan (hisab) biasa, yakni penambahan, pengurangan, perkalian dan pembagian.

Secara garis besar sistem hisab awal bulan qamariyah dalam ilmu falak, terbagi menjadi dua bagian, yaitu hisab urfi dan hisab hakiki. Hisab urfi merupakan sistem hisab yang berdasarkan pada peredaran rata-rata bulan mengelilingi bumi dann ditetapkan secara konvensional. Sedangkan hisab hakiki dibagi menjadi tiga kelompok, yakni hisab hakiki taqribi, hisab hakiki tahqiqi, dan hisab hakiki tadqiqi (al ashri) (Azhari, 2005: 79).

Pertama, hisab haqiqi taqribi, ialah perhitungan astronomis berdasarkan gerak benda langit (misalnya bulan) rata-rata, sehingga hasilnya masih bisa untuk dikoreksi untuk menghasilkan hasil hisab yang lebih akurat. Misalnya, ketika menghitung hilal terdapat dua cara, yaitu (Ghurub Matahari-Ijtima') atau waktu terbenam matahari dikurangi waktu Ijtima', kemudian dibagi dua. Kitab-kitab falak yang digolongkan dalam sistem hisab ini di antaranya Sullam al Nayyirain, Syams al Hilal, Risalah al Qamarain, Fath al Rauf al Mannan, Tadzkirah al Ikhwan, dan lain sebagainya.

Kedua, hisab hakiki tahkiki, yaitu sistem perhitungan posisi benda langit berdasarkan gerak benda langit yang sebenarnya, sehingga hasilnya cukup akurat. Dalam sistem ini sudah menggunakan rumus segi tiga bola, yang memperhitungkan seperti nilai deklinasi matahari, deklinasi bulan, azimuth matahari dan bulan, serta lainnya. Kitab-kitabb yang tergolong dalam sistem hisab ini misalnya al Khulashah al Wafiyah, Nur al Anwar, al Mathla' al Said, al Manahij al Hamidiah, dan masih banyak lagi.

Ketiga, hisab hakiki tadqiqi/al ashri (kontemporer), yakni sistem hisab tentang posisi benda-benda langit yang telah menggunakan rumus-rumus segi tiga bola (spherical trigonometry) yang disertai koreksi-koreksi yang 
cukup signifikan, sehingga diperoleh hasil hisab yang akurat dan mendekati pada kenyataan. Adapun yang termasuk dalam sistem ini misalnya, kitab al durr al aniq, almanak nautika, almanak astronomi, newcomb, dan lain sebagainya (Izzuddin, 2007: 88).

Berdasarkan pembagian sistem hisab di atas, penulis tertarik untuk melakukan kajian hisab awal bulan qamariah sistem hakiki tahkiki terhadap salah satu kitab falak karya Rektor pertama IAIN Walisongo Semarang, KH. Zubair Umar Jaelani, yang berjudul al Khulashah al Wafiyah. Kajian ini menarik karena sistem hisab awal bulan qamariah dalam kitab ini antara hisab hakiki taqribi dan hakiki tahkiki saling berkaitan, tidak seperti kitabkitab falak lainnya yang memisahkan antara hisab hakiki taqribi dan hakiki tahkiki. Selain itu, istilah-istilah falak yang digunakan dalam kitab ini cendrung berbeda dibanding dengan istilah-istilah falak yang digunakan pada kitab-kitab falak lainnya. Untuk lebih jelasnya, akan dikaji dalam pembahasan selanjutnya.

\section{METODE PENELITIAN}

Metode yang digunakan dalam penulisan artikel ini adalah studi kepustakaan dengan pendekatan kualitatif. Pendekatan kualitatif digunakan untuk menghasilkan informasi berupa data diskripsi dan catatan yang terdapat dalam teks yang diteliti. Sumber data yang digunakan adalah data primer dan data sekunder. Data primer berupa Kitab al Khulashah al Wafiyah karya KH. Zubair Umar Jaelani. Sedangkan data sekunder berupa buku-buku, artikel, majalah dan lain-lain. Metode analisis data dipakai adalah analisis diskriptif. Dengan analisis diskriptif ini akan diperoleh suatu gambaran dan keterangan secara obyektif, sistematis, kritis, dan jelas mengenai langkah-langkah dalajriyam penentuan hisab awal bulan hijriyah berdasarkan Kitab al Khulashah al Wafiyah.

\section{PEMBAHASAN}

\section{Profil KH. Zubair Umar Jaelani dan Kitab al Khulashah al Wafiyah}

Zubair Umar Jaelani adalah salah seorang ulama yang terkenal sebagai pakar ilmu Falak. Beliau lahir di padangan Kecamatan Padangan Kabupatenn Bojonegoro Jawa Timur pada tanggal 16 September 1908 M. Pada usia delapan tahun, beliau belajar di sekolah Diniyah Madrasatul Ulum yang berada dalam komplek Masjid Besar Bojonegoro selama lima tahun (1916-1921). Setelah itu, beliau melakukan pengembaraan intelektual ke beberapa pesantren di Jawa. Pada awalnya Zubair muda belajar di Pesantren Tremas, Pacitan Jawa Timur (1921-1925) di bawah asuhan KH. Dimyathi Abdullah (w. 1934). Pada waktu itu pesantren 
Tremas menjadi kiblat ilmu bagi para santri dan namanya harus sampai ke Makkah al Mukarramah.

Dari pesantren Tremas, Zubair berguru pada Kiai Amir bin Idris (w. 1938) di pesantren Simbang Kulon Pekalongan Jawa Tengah (19251926). Selepas dari Pekalongan, ia menuju ke pesantren Tebu Ireng berguru dengan Kiai Hasyim Asy'ari selama lebih kurang tiga tahun (1926-1929). Pada pesantren ini Zubair muda mempunyai ketertarikan yang luar iasa terhadap ilmu Falak.

Setelah dari Tebu Ireng, beliau melanjutkan belajar ke Kota Suci Makkah. Beliau mengembara di Negeri Makkah lebih kurang lima tahun (1930-1935). Harapan beliau untuk melanjutkan belajar ilmu Falak ke beberapa ulama di sana agak terhenti, karena para ulama yang diharapkan akan menjadi gurunya dalam ilmu Falak kompetensinya jauh di bawah Zubair. Justru banyak ulam di Makkah kala itu yang belajar Falak kepada beliau. Akhirnya beliau pindah ke Madinah, kemudian ke Damaskus Syiria dengan harapan akan menemukan sesosok guru yang mumpuni dalam ilmu Falak. Namun hasilnya sama ketika beliau masih di Makkah, yakni belum menemukan sosok guru tersebut.

Lalu ada saran dari beberapa ulama di sana agar beliau melanjutkan perjalanan ilmiahnya ke al Azhar Mesir. Akhirnya beliau menemukan guru yang diharapkan untuk melanjutkan belajar ilmu Falak. Saat itu Jabatan Rektor al Azhar dipegang oleh Syekh Mushthofa al Maroghi, penulis kitab Tafsir al Maroghi.

Di al Azhar Kiai Zubair bertemu dengan Syekh Umar Hamdan al Mahrasi (w. 1949), seorang ulama multi talenta yang punya banyak murid yang tersebar di Kairo, Makkah, dan Indonesia. Setelah dianggap mumpuni dalam ilmu Falak, Kiai Zubair diangkat sebagai dosen ilmu Falak di al Azhar pada tahun 1931-1935.

Selama di al Azhar Kiai Zubair menyusun naskah bukunya dalam ilmu Falak yang pada kemudian hari diterbitkan di Indonesia sekitar tahun 1937 dengan judul al Khulashah al Wafiyah. Ketika mengajar di al Azhar, Kiai Zubair tidak pernah menggunakan buku pegangan tertentu, karena materi yang akan disampaikan ke mahasiswa sudah dikuasai dengan sangat baik. Oleh karenanya, para mahasiswa yang aktif akan menulis setiap apa yang disampaikan Kiai Zubair.

Sepulang dari Kairo, beliau menetap bersama keluarga Istrinya di Suruh Salatiga, pada tahun 1935. Beberapa tahun kemudian setelah Indonesia Merdeka, beliau mendirikan Pesantren Luhur Salatiga yang kemudian hari menjadi IKIP NU, lalu berubah menjadi Fakultas Tarbiyah IAIN Walisongo. Setelahnya berubah menjadi STAIN Salatiga (kini IAIN Salatiga). Selain sibuk mengajar di masyarakat, beliau juga pernah diminta mengajar di Madrasah Salafiyah di Pesantren Tebuireng. 
Perjalanan karir beliau di Indonesia dimulai dengan menjadi Penghulu pada Pengadilan Negeri Salatiga (1945-1947), Penghulu Kabupaten Semarang (1947-1951), Koordinator Urusan Agama Kerisidenan Pati (1954-1956), Ketua Mahkamah Islam Tinggi yang berkedudukan di Surakarta 1962-1970, serta menjadi dosen dan diangkat menjadi Rektor IAIN Walisongo Semarang sejak 5 Mei 1970 hingga tahun 1972. Beliau juga pernah dianugrahigelar doktor kehormatan (honoris causa) oleh Universitas Nahdhatul Ulama (UNNU) Surakarta tahun 1958, karena perestasi beliau pernah mengajar di Universitas bergengsi al Azhar Kairo.

Dalam organisasi, beliau pernah menjadi ketua cabang NU Kabupaten Semarang (1945), Komandan Barisan Kiai-Barisan Sabilillah Kabupaten Semarang di masa Revolusi Kemerdekaan mengusir Belanda, ketua Syuriah Partai Masyumu cabang Kabupaten Semarang dan kota Salatiga tahun 1952-1956, Rais Syuriah NU Wilayah Profinsi Jawa Tengah 1956-1970, lalu anggota Syuriah PBNU di era kepemimpinan Rais 'Am KH. Abdul Wahab Chasbullah periode 1967-1971.

Pada tahun 1971, Kiai Zubair menerima hibah tanah dari pemerintah seluas enam hektar untuk mendirikan pesantren. Kemudian pada tahun 1977 beliau mendirikan pesanntren dan diberi nama Pondok Pesantren Joko Tingkir. Pada tanggal 10 Desember 1990/24 Jumadi Awal 1411 Kiai Zubair Umar Jaelani tutup usia dan dimakamkan di dalam komplek pemakaman Kauman, di belakang masjid Baitul Atiq Salatiga.

\section{Hisab Hakiki Tahkiki Kitab al Khulashah al Wafiyah}

Dalam hisab hakiki tahkiki kitab al Khulashah al Wafiyah ini, penulis menggunakan koordinat markaz menara al Husna Masjid Agung Jawa Tengah, yakni $-6^{\circ} 59^{\prime} 4.98^{\prime \prime}$ LS, $110^{\circ} 26^{\prime}$ 47.63" (Koordinat ditentukan menggunakan alat GPS dan Google Earth) dengan ketinggian tempat 95 meter di atas permukaan laut. Adapun langkah-langkah hisab hakiki tahkiki dalam kitab ini adalah sebagai berikut:

\section{Menghitung Matahari Terbenam}

Untuk menghitung terbenam matahari diawali dengan menghitung sudut waktu (t) matahari saat ghurub dengan rumus sebagai berikut :

$\operatorname{Cos} t=\sin h / \cos \phi / \cos \delta-\tan \phi^{*} \tan \delta$

Keterangan:

$\mathrm{h}=$ tinggi matahari saat ghurub dan dapat diperoleh dengan rumus : $(\mathrm{ku}+\mathrm{sd}+\mathrm{ref})$

$\mathrm{ku}=$ kerendahann ufuk atau dip adalah beda sudut karena ketinggian dan dapat diperoleh dengan rumus $0^{\circ} 1.76^{*} \sqrt{\mathrm{m}}_{\mathrm{m}}$ 
$\mathrm{ku}$ untuk Menara al Husna Masjid Agung Jawa Tengah : $0^{\circ} 1.76^{*} \sqrt{95}=$ $0^{\circ} 17^{\prime} 9.26^{\prime \prime}$

$\mathrm{Sd}=$ semidiameter matahari rata-rata sebesar $0^{\circ} 16^{\prime}$

Ref $=$ refraksi atau pembiasan cahaya matahari saat ghurub, besarnya adalah $0^{\circ} 34^{\prime}$ yang diperoleh dari rumus ref = $0.0167 / \tan (\mathrm{h}+7.31 /(\mathrm{h}+4.4))$

h matahari $(\mathrm{hm})=-\left(0^{\circ} 17^{\prime} 9.26^{\prime \prime}+0^{\circ} 16^{\prime}+0^{\circ} 34^{\prime}\right)=-1^{\circ} 7^{\prime} 9.26^{\prime \prime}$

$\phi=$ lintang Tempat (dalam hal ini Menara Masjid Agung Jawa Tengah), sebesar $-6^{\circ} 59^{\prime} 4.98^{\prime \prime}$ LS

$\delta=$ deklinasi matahari (mail al syams) yang dapat dihitung dengan rumus: $\sin \delta=\sin \mathrm{TS}^{*} \sin \mathrm{MA}$

TS = thul al syams, dalam hal ini sebesar $2 \mathrm{~b} 4^{\circ} 27^{\prime}+36^{\prime} 58^{\prime \prime}$ (pk. 17 pk.2 $=15$ jam $)=2 b 5^{\circ} 3^{\prime} 58^{\prime \prime}$.

$\mathrm{MA}=$ mail a'dzom, yaitu $23^{\circ} 27^{\prime}$

$\operatorname{Sin} \delta=\sin 65^{\circ} 3^{\prime} 58^{\prime \prime *} \sin 23^{\circ} 27^{\prime}$

$=21^{\circ} 9^{\prime} 10.38^{\prime \prime}$

Menghitung sudut waktu matahari $(\mathrm{t})$

$\operatorname{Cos} \mathrm{t}=\sin \mathrm{h} / \cos \phi / \cos \delta-\tan \phi^{*} \tan \delta$

$=\sin -1^{\circ} 7^{\prime} 9.26^{\prime \prime} / \cos -6^{\circ} 59^{\prime} 4.98^{\prime \prime} / \cos 21^{\circ} 9^{\prime} 10.38^{\prime \prime}-\tan -6^{\circ}$ $59^{\prime} 4.98^{\prime \prime *} \tan 21^{\circ} 9^{\prime} 10.38^{\prime \prime}$

$\mathrm{t} \quad=88^{\circ} 29^{\prime} 33.96^{\prime \prime}$

$=5 \mathrm{j} 53 \mathrm{~m} 58.26 \mathrm{~d}$

Menghitung terbenam matahari dengan WIB

Pk. 12+t-e+(BD-BT)/15

Pk. $12=$ mer pass (zawal)

$\mathrm{T}=$ sudut matahari saat ghurub

$\mathrm{e}=$ equation of time (daqoiq ta' dil zaman), $0^{\circ} 3^{\prime}$

$\mathrm{BD}=$ bujur daerah $\left(\mathrm{WIB}=105^{\circ}, \mathrm{WITA}=120^{\circ}, \mathrm{WIT}=135^{\circ}\right)$

$\mathrm{BT}=$ Bujur Tempat, Menara al Husna Masjid Agung Jawa Tengah, yaitu: $110^{\circ} 26^{\prime} 47.63^{\prime \prime}$

Terbenam matahari dengan WIB pada hari Jum'at Legi, 29 Sya'ban $1438 \mathrm{H}$ (26 Mei $2017 \mathrm{M})$ adalah:

Pk. 12+5j 53m 58.26d-(0j 3m)+(105-110 26' 47.63")/15

Pk. 17:29:11.09 WIB dengan ihtiyat dibulatkann menjadi 17:30 WIB

Zawal di Makkah

Beda waktu Arab dan WIB

Pk. 12:17:41.72

Zawal di Makkah dengan waktu WIB

Terbenam matahari di Menara al Husna

Pk. 16:17:41.72

Selisih waktu dari Zawal Makkah

Pk. 17:30:00.00 -

$1 \mathrm{j} 12 \mathrm{~m} \mathrm{18.28d} \mathrm{(1j} \mathrm{12m)}$

2. Menghitung Thul al Syams dan Thul al Qamar Saat Ghurub Hari Jum'at Legi, Akhir Sya'ban 1438 H/ 26 Mei 2017 M pk. 17.30 WIB (1 Jam 12 Menit Dari Zawal di Ka'bah) 
Hisab Awal Bulan Hijriyah dalam KItab....

\begin{tabular}{|c|c|c|c|c|c|c|c|c|c|c|c|c|c|c|c|c|c|c|c|c|c|}
\hline \multicolumn{4}{|c|}{ العقدة } & \multicolumn{4}{|c|}{ خاصة القمر } & \multicolumn{4}{|c|}{ وسط القمر } & \multicolumn{4}{|c|}{ خاصة الثمس } & \multicolumn{4}{|c|}{ وسط الثُمس } & \multirow[b]{2}{*}{ b } & \multirow{2}{*}{ الحركات } \\
\hline " & 1 & $\circ$ & $\mathrm{b}$ & " & 1 & $\circ$ & B & " & 1 & $\circ$ & B & " & 1 & $\circ$ & $\mathrm{b}$ & " & 1 & $\circ$ & B & & \\
\hline 7 & 25 & 22 & 1 & 39 & 0 & 12 & 8 & 24 & 24 & 11 & 4 & 6 & 50 & 17 & 0 & 48 & 50 & 0 & 4 & 2 & 1410 \\
\hline 28 & 40 & 26 & 4 & 47 & 48 & 25 & 2 & 50 & 45 & 11 & 2 & 47 & 11 & 10 & 2 & 23 & 40 & 10 & 2 & 6 & 27 \\
\hline 35 & 5 & 19 & 6 & 26 & 49 & 7 & 11 & 14 & 10 & 23 & 6 & 53 & 1 & 28 & 2 & 11 & 31 & 11 & 6 & 1 & 1437 \\
\hline 42 & 57 & 10 & 0 & 10 & 27 & 4 & 6 & 51 & 30 & 27 & 6 & 8 & 1 & 24 & 6 & 44 & 1 & 24 & 6 & 4 & Rajab \\
\hline 17 & 3 & 0 & 7 & 36 & 16 & 12 & 5 & 5 & 41 & 20 & 1 & 1 & 3 & 22 & 9 & 55 & 32 & 5 & 1 & 5 & Jumlah \\
\hline 9 & 32 & 1 & 0 & 5 & 53 & 18 & 0 & 56 & 6 & 22 & 0 & 57 & 34 & 28 & 0 & 2 & 35 & 28 & 0 & 1 & 29 hari \\
\hline 26 & 35 & 1 & 7 & 41 & 9 & 1 & 6 & 1 & 48 & 12 & 2 & 58 & 37 & 20 & 10 & 57 & 7 & 4 & 2 & 6 & jumlah \\
\hline 8 & 0 & 0 & 0 & 39 & 32 & 0 & 0 & 56 & 32 & 0 & 0 & 28 & 2 & 0 & 0 & 28 & 2 & 0 & 0 & & 1 jam \\
\hline 2 & 0 & 0 & 0 & 32 & 6 & 0 & 0 & 35 & 6 & 0 & 0 & 30 & 0 & 0 & 0 & 30 & 0 & 0 & 0 & & $12 \mathrm{jam}$ \\
\hline 36 & 35 & 1 & 7 & 52 & 48 & 1 & 6 & 32 & 27 & 13 & 2 & 56 & 40 & 20 & 10 & 55 & 10 & 4 & 2 & 6 & Jumlah \\
\hline 34 & 5 & 0 & $(+)$ & 4 & 7 & 0 & $(-)$ & 4 & 7 & 0 & $(-)$ & 1 & & & & 1 & 12 & 1 & $(+)$ & & Ta'dil \\
\hline 10 & 41 & 1 & 7 & 48 & 41 & 1 & 6 & 28 & 20 & 13 & 2 & & & & & & 22 & 5 & 2 & & $\begin{array}{l}\text { Thul al } \\
\text { Svams }\end{array}$ \\
\hline & & & & 14 & 20 & 0 & $(+)$ & 14 & 20 & 0 & $(+)$ & 2 & & & & & & & & & \\
\hline & & & & 2 & 2 & 2 & 6 & 42 & 40 & 13 & 2 & & & & & & & & & & \\
\hline & & & & 36 & 14 & 0 & $(-)$ & 42 & 12 & 0 & $(+)$ & 3 & & & & & & & & & \\
\hline & & & & 26 & 47 & 1 & 6 & 24 & 53 & 13 & 2 & & & & & & & & & & \\
\hline & & & & & & & & 17 & 10 & 0 & $(+)$ & 4 & & & & & & & & & \\
\hline & & & & & & & & 41 & 3 & 14 & 2 & & & & & & & & & & \\
\hline & & & & & & & & 31 & 3 & 0 & $(+)$ & 5 & & & & & & & & & \\
\hline & & & & & & & & 12 & 7 & 14 & 2 & & & & & & & & & & \\
\hline
\end{tabular}

“4 ○ b

$56402010 \quad$ Dalil Awal (Khosshoh al Syams)

Ta'dil al Syams

$041301(+) \quad 10 \mathrm{~b} 20^{\circ}$

$321101(+) \quad 10 \mathrm{~b} 21^{\circ}$

$1^{\circ} 13^{\prime} 4^{\prime \prime}+0^{\circ} 40^{\prime} 56^{\prime \prime *}\left(1^{\circ} 11^{\prime} 32^{\prime \prime}-1^{\circ} 13^{\prime} 4^{\prime \prime}\right)$

$1^{\circ} 12^{\prime} 1.24^{\prime \prime}\left(1^{\circ} 12^{\prime} 1^{\prime \prime}\right) \rightarrow$ Ta'dil al Syams

$56402010 \quad$ Dalil Awal (Khosshoh al Syams)

Ta'dil Awal lil Qomar

$1007 \quad(-) \quad 10 \mathrm{~b} 20^{\circ}$

$0107 \quad(-) \quad 10 \mathrm{~b} 21^{\circ}$

$-0^{\circ} 7^{\prime} 10^{\prime \prime}+0^{\circ} 40^{\prime} 56^{\prime \prime *}\left(-0^{\circ} 7^{\prime} 1^{\prime \prime}-\left(-0^{\circ} 7^{\prime} 10^{\prime \prime}\right)\right)$

$-0^{\circ} 7^{\prime} 3.86^{\prime \prime}\left(-0^{\circ} 7^{\prime} 4^{\prime \prime}\right)$

$040700 \quad$ Ta'dill Awal lil Qomar 
32271302 Wasath al Qomar

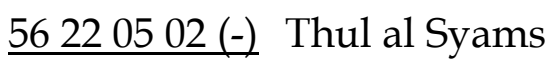

$36040800 \quad$ Sisa

$\underline{36040800(+)}$

$12091600 \quad$ Jumlah

$\underline{52480106(-)}$

$20201406 \quad$ Dalil Tsani

Ta'dil Tsani lil Qomar

$461900(+) \quad 6 \mathrm{~b} 14^{\circ}$

$092100(+) \quad 6 \mathrm{~b} 15^{\circ}$

$0^{\circ} 19^{\prime} 46^{\prime \prime}+0^{\circ} 20^{\prime} 20^{\prime \prime *}\left(0^{\circ} 21^{\prime} 9^{\prime \prime}-0^{\circ} 19^{\prime} 46^{\prime \prime}\right)$

$0^{\circ} 20^{\prime} 14.13^{\prime \prime}\left(0^{\circ} 20^{\prime} 14^{\prime \prime}\right)$

$142000 \quad$ Ta'dil Tsani lil Qomar

56402010 Dalil Awal (Khosshoh al Syams)

$491400(-) \quad 10 b 20^{\circ}$

$301400(-) \quad 10 b 21^{\circ}$

$-0^{\circ} 14^{\prime} 49^{\prime \prime}+0^{\circ} 40^{\prime} 56^{\prime \prime *}\left(-0^{\circ} 14^{\prime} 30^{\prime \prime}-\left(-0^{\circ} 14^{\prime} 49^{\prime \prime}\right)\right)$

$-0^{\circ} 14^{\prime} 36.04^{\prime \prime}\left(-0^{\circ} 14^{\prime} 36^{\prime \prime}\right)$

$361400(-) \quad$ Ta'dil al Khasshah

$26470106 \quad$ Dalil Tsalits

$060700(+) \quad 6 b 1^{\circ}$

$111400(+) \quad 6 b 2^{\circ}$

$0^{\circ} 7^{\prime} 6^{\prime \prime}+0^{\circ} 47^{\prime} 26^{\prime \prime *}\left(0^{\circ} 7^{\prime} 11^{\prime \prime}-0^{\circ} 7^{\prime} 6^{\prime \prime}\right)$

$0^{\circ} 12^{\prime} 41.99^{\prime \prime}\left(0^{\circ} 12^{\prime} 42^{\prime \prime}\right)$

$421200 \quad$ Ta'dil Tsalits

24531302 Wasath al Qomar

$56220502(-)$ Thul al Syams

$28300800 \quad$ Dalil Robi'

$410900(+) \quad 0 b 8^{\circ}$

$521000(+) \quad 0 b 9^{\circ}$

$0^{\circ} 9^{\prime} 41^{\prime \prime}+0^{\circ} 30^{\prime} 28^{\prime \prime *}\left(0^{\circ} 10^{\prime} 52^{\prime \prime}-0^{\circ} 9^{\prime} 41^{\prime \prime}\right)$

$0^{\circ} 10^{\prime} 17.05^{\prime \prime}\left(0^{\circ} 10^{\prime} 17^{\prime \prime}\right)$ 
$171000(+) \quad$ Ta'dil Rabi'

$56402010 \quad$ Dalil Awal (Khosshoh al Syams)

Ta'dil al Uqdah

$3905(+) \quad 10 \mathrm{~b} 20^{\circ}$

$3205(+) \quad 10 \mathrm{~b} 21^{\circ}$

$0^{\circ} 5^{\prime} 39^{\prime \prime}+0^{\circ} 40^{\prime} 56^{\prime \prime *}\left(0^{\circ} 5^{\prime} 32^{\prime \prime}-0^{\circ} 5^{\prime} 39^{\prime \prime}\right)$

$0^{\circ} 5^{\prime} 34.22^{\prime \prime}\left(0^{\circ} 5^{\prime} 34^{\prime \prime}\right)$

$340500(+) \quad$ Ta'dil al Uqdah

41031402 Wasath al Qamar

$10410107(+)$ al Uqdah

$51441509 \quad$ Dalil Khamis

Ta'dil Khamis

$220300(+) \quad 9 \mathrm{~b} 15^{\circ}$

$340300(+) \quad 9 \mathrm{~b} 16^{\circ}$

$0^{\circ} 3^{\prime} 22^{\prime \prime}+0^{\circ} 44^{\prime} 51^{\prime \prime *}\left(0^{\circ} 3^{\prime} 34^{\prime \prime}-0^{\circ} 3^{\prime} 22^{\prime \prime}\right)$

$0^{\circ} 3^{\prime} 30.97^{\prime \prime}\left(0^{\circ} 3^{\prime} 31^{\prime \prime}\right)$

$310300(+) \quad$ Ta'dil Khamis

\section{Data Astronomis Matahari dan Bulan}

Diketahui:

Lintang Tempat $\quad(\phi x)=-6^{\circ} 59^{\prime} 4.98^{\prime \prime}$ LS

Bujur Tempar $(\lambda x) \quad=110^{\circ} 26^{\prime} 47.63^{\prime \prime}$ BT

Thul al Syams (TS) $\quad=2 \mathrm{~b} 05^{\circ} 22^{\prime} 55^{\prime \prime}\left(65^{\circ} 22^{\prime} 55^{\prime \prime}\right)$

Thul al Qamar (TQ) = 2b 140 $07^{\prime} 13^{\prime \prime}\left(74^{\circ} 07^{\prime} 13^{\prime \prime}\right)$

Dalil Khamis (DK) $=285^{\circ} 44^{\prime} 51^{\prime \prime}$

Terbenam Matahari $=$ Pk. 17:30 WIB

Ijtima' $\quad=$ Pk. 02:45 WIB

Umur Bulan $\quad=14$ Jam 45 Menit

Mail al Syams (סo) saat terbenam:

Sin $\delta o=$ Sin TS* ${ }^{*}$ in Mail al A'dzom (MA)

$=\sin 65^{\circ} 22^{\prime} 55^{\prime \prime *} \sin 23^{\circ} 27^{\prime}$

So $=21^{\circ} 12^{\prime} 34^{\prime \prime}$

Qous Bu'd al Quthr li al Syams (BQS): 
$\operatorname{Sin} \mathrm{BQS}=\operatorname{Sin} \delta \mathrm{o}^{*} \sin \phi \mathrm{x}$

$$
=\operatorname{Sin} 21^{\circ} 12^{\prime} 34^{\prime \prime *} \sin -6^{\circ} 59^{\prime} 4.98^{\prime \prime}
$$

BQS $=-2^{\circ} 31^{\prime} 17^{\prime \prime}$

Qous al Ashl al Muthlaq li al Syams (AMS):

$\operatorname{Sin} \mathrm{AMS}=\cos \delta \mathrm{o}^{*} \cos \phi \mathrm{x}$

$$
=\cos 21^{\circ} 12^{\prime} 34^{\prime \prime *} \cos -6^{\circ} 59^{\prime} 4.98^{\prime \prime}
$$

AMS $=67^{\circ} 43^{\prime} 14^{\prime \prime}$

Nishf al Fudhlah li al Syams (NFS):

$\operatorname{Sin} \mathrm{NFS}=\sin \mathrm{BQS} / \sin \mathrm{AMS}$

$$
\begin{aligned}
& =\sin -2^{\circ} 31^{\prime} 17^{\prime \prime} / \sin 67^{\circ} 43^{\prime} 14^{\prime \prime} \\
& =-2^{\circ} 43^{\prime} 30^{\prime \prime}
\end{aligned}
$$

Nishf Qous al Nahar (NQN):

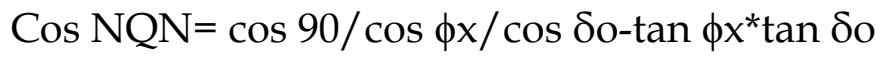

$=\cos 90 / \cos -6^{\circ} 59^{\prime} 4.98^{\prime \prime} / \cos 21^{\circ} 12^{\prime} 34^{\prime \prime}-\tan -6^{\circ} 59^{\prime} 4.98^{\prime \prime *} \tan$ $21^{\circ} 12^{\prime} 34^{\prime \prime}$

$\mathrm{NQN}=87^{\circ} 16^{\prime} 30^{\prime \prime}$

Mathali al Zawal (MZ)/Mathali' al Falakiyah li al Syams:

$\operatorname{Sin} \mathrm{MZ}=\cos \mathrm{TS} / \cos \delta \mathrm{o}$

$$
=\cos 65^{\circ} 22^{\prime} 55^{\prime \prime} / \cos 21^{\circ} 12^{\prime} 34^{\prime \prime}
$$

$\mathrm{MZ}=153^{\circ} 27^{\prime} 34^{\prime \prime}$

Mathali' al Ghurub li al Syams (MGS):

MGS $=\mathrm{NQN}+\mathrm{MZ}$

$=87^{\circ} 16^{\prime} 30^{\prime \prime}+153^{\circ} 27^{\prime} 34^{\prime \prime}$

MGS $=240^{\circ} 44^{\prime} 4^{\prime \prime}$

Sa'at Maghrib al Syams (SMS) / Azimuth Matahari saat terbenam:

$\operatorname{Sin} \mathrm{SMS}=\sin \delta \mathrm{o} / \cos \phi \mathrm{x}$

$$
\begin{aligned}
& =\sin 21^{\circ} 12^{\prime} 34^{\prime \prime} / \cos -6^{\circ} 59^{\prime} 4.98^{\prime \prime} \\
& =21^{\circ} 22^{\prime} 33^{\prime \prime}
\end{aligned}
$$

Mail al Qamar al Awal (MQA):

$\operatorname{Sin} \mathrm{MQA}=\operatorname{Sin} \mathrm{TQ}^{*} \sin$ Mail al $A^{\prime}$ dzom (MA)

$$
=\sin 74^{\circ} 07^{\prime} 13^{\prime \prime *} \sin 23^{\circ} 27^{\prime}
$$

MQA $=22^{\circ} 30^{\prime} 18^{\prime \prime}$ 
Mail al Qamar al Tsani (MQS):

Tan MQS $=$ Sin $\mathrm{TQ}^{*} \tan$ Mail al A'dzom (MA)

$=\sin 74^{\circ} 07^{\prime} 13^{\prime \prime} * \tan 23^{\circ} 27^{\prime}$

MQS $=22^{\circ} 38^{\prime} 49^{\prime \prime}$

Ard al Qamar (AQ):

$\operatorname{Sin} \mathrm{AQ}=\sin \mathrm{DK}{ }^{*} \sin$ Ard al Qamar al Kulli $\left(5^{\circ} 1^{\prime}\right)$

$$
=\sin 285^{\circ} 44^{\prime} 51^{\prime \prime} * \sin 5^{\circ} 1^{\prime}
$$

$\mathrm{AQ}=-4^{\circ} 49^{\prime} 40^{\prime \prime}$

Hisshah al Bu'd (HB):

$\mathrm{HB}=\mathrm{AQ}+\mathrm{MQS}$ $=-4^{\circ} 49^{\prime} 40.51^{\prime \prime}+22^{\circ} 38^{\prime} 49^{\prime \prime}$

$\mathrm{HB}=17^{\circ} 49^{\prime} 9^{\prime \prime}$

Bu'd al Qamar an Mu'addal (BQ):

$\operatorname{Sin} \mathrm{BQ}=\cos \mathrm{MA}^{*} \sin \mathrm{HB} / \cos \mathrm{MQS}$ $=\cos 23^{\circ} 27^{\prime *} \sin 17^{\circ} 49^{\prime} 9^{\prime \prime} / \cos 22^{\circ} 38^{\prime} 49^{\prime \prime}$

$\mathrm{BQ}=17^{\circ} 42^{\prime} 34^{\prime \prime}$

Qous Bu'd al Quthr li al Qamar (BQQ):

$\operatorname{Sin} \mathrm{BQQ}=\operatorname{Sin} \mathrm{BQ}^{*} \sin \phi \mathrm{x}$

$$
=\operatorname{Sin} 17^{\circ} 42^{\prime} 34^{\prime \prime *} \sin -6^{\circ} 59^{\prime} 4.98^{\prime \prime}
$$

BQQ $=-2^{\circ} 7^{\prime} 12^{\prime \prime}$

Qous al Ashl al Muthlaq li al Qamar (AMQ):

$\operatorname{Sin} \mathrm{AMQ}=\cos \mathrm{BQ}^{*} \cos \phi \mathrm{x}$

$$
=\cos 17^{\circ} 42^{\prime} 34^{\prime \prime *} \cos -6^{\circ} 59^{\prime} 4.98^{\prime \prime}
$$

$\mathrm{AMQ}=71^{\circ} 0^{\prime} 14^{\prime \prime}$

Nishf al Fudhlah li al Qamar (NFQ):

$\operatorname{Sin} \mathrm{NFQ}=\sin \mathrm{BQQ} / \sin \mathrm{AMQ}$

$$
=\sin -^{\circ} 7^{\prime} 12^{\prime \prime} / \sin 71^{\circ} 0^{\prime} 14^{\prime \prime}
$$

NFQ $=-2^{\circ} 14^{\prime} 31^{\prime \prime}$

Nishf Qous al Dzuhur (NQD):

$\operatorname{Cos} \mathrm{NQD}=\cos 90 / \cos \phi \mathrm{x} / \cos \mathrm{BQ}-\tan \phi \mathrm{x}^{*} \tan \mathrm{BQ}$ $=\cos 90 / \cos -6^{\circ} 59^{\prime} 4.98^{\prime \prime} / \cos 17^{\circ} 42^{\prime} 34^{\prime \prime}-\tan -6^{\circ} 59^{\prime} 4.98^{\prime \prime *} \tan$ $17^{\circ} 42^{\prime} 34^{\prime \prime} 2$ 
$\mathrm{NQD}=87^{\circ} 45^{\prime} 29^{\prime \prime}$

Mathali al Tawassuth (MT)/Mathali' al Falakiyah li al Qamar:

$\operatorname{Sin} \mathrm{MT}=\cos \mathrm{TQ} / \cos \mathrm{BQ}$

$$
=\cos 74^{\circ} 07^{\prime} 13^{\prime \prime} / \cos 17^{\circ} 42^{\prime} 34^{\prime \prime}
$$

MT $=163^{\circ} 18^{\prime} 28^{\prime \prime}$

Mathali' al Ghurub li al Qamar (MGQ):

MGQ = NQD+MT

$$
=87^{\circ} 45^{\prime} 29^{\prime \prime}+163^{\circ} 18^{\prime} 28^{\prime \prime}
$$

MGQ = 251 $3^{\prime} 57^{\prime \prime}$

Qous Mukts al Hilal (QMH):

$\mathrm{QMH}=\mathrm{MGQ}-\mathrm{MGS}$

$$
\begin{aligned}
& =251^{\circ} 3^{\prime} 57^{\prime \prime}-240^{\circ} 44^{\prime} 4^{\prime \prime} \\
& =10^{\circ} 19^{\prime} 53^{\prime \prime}
\end{aligned}
$$

Fadl al Dair (FD):

FD = NQD-QMH

$$
\begin{aligned}
& =87^{\circ} 45^{\prime} 29^{\prime \prime}-10^{\circ} 19^{\prime} 53^{\prime \prime} \\
& =77^{\circ} 25^{\prime} 35^{\prime \prime}
\end{aligned}
$$

Irtifa' al Hilal (IH):

$\operatorname{Sin} \mathrm{Hs}=\cos \mathrm{FD}^{*} \sin \mathrm{AMQ}$

$$
=\cos 77^{\circ} 25^{\prime} 35^{\prime \prime *} \sin 71^{\circ} 0^{\prime} 14^{\prime \prime}
$$

Hs = $11^{\circ} 52^{\prime} 43^{\prime \prime}$

$\mathrm{IH}=\mathrm{Hs}+\mathrm{BQQ}$

$$
\begin{aligned}
& =11^{\circ} 52^{\prime} 43^{\prime \prime}+-2^{\circ} 7^{\prime} 12^{\prime \prime} \\
& =9^{\circ} 45^{\prime} 31^{\prime \prime}
\end{aligned}
$$

Simt al Irtifa' (SI):

$\operatorname{Cos} \mathrm{SI}=\sin \mathrm{FD}^{*} \cos \mathrm{BQ} / \cos \mathrm{IH}$

$$
\begin{aligned}
& =\sin 77^{\circ} 25^{\prime} 35^{\prime \prime *} \cos 17^{\circ} 42^{\prime} 34^{\prime \prime} / \cos 9^{\circ} 45^{\prime} 31^{\prime \prime} \\
& =19^{\circ} 22^{\prime} 0^{\prime \prime}
\end{aligned}
$$

Nur al Hilal (NH):

$\mathrm{NH}=(\mathrm{TQ}-\mathrm{TS})^{*} 04^{\prime}+(\mathrm{AQ} / 60)$

$$
\begin{aligned}
& =\left(74^{\circ} 07^{\prime} 13^{\prime \prime}-65^{\circ} 22^{\prime} 55^{\prime \prime}\right) * 04^{\prime}+\left(-4^{\circ} 49^{\prime} 40^{\prime \prime} / 60\right) \\
& =0.66 \%
\end{aligned}
$$


Al Mahfudz (M):

$\mathrm{M} \quad=$ SI-SMS

$$
\begin{aligned}
& =19^{\circ} 22^{\prime} 0^{\prime \prime}-21^{\circ} 22^{\prime} 33^{\prime \prime} \\
& =-2^{\circ} 0^{\prime} 32^{\prime \prime} \text { (sebelah selatan matahari) }
\end{aligned}
$$

Saat al Maghrib li al Qamar (SMQ):

$\sin \mathrm{SMQ}=\sin \mathrm{BQ} / \cos \phi \mathrm{x}$

$$
\begin{aligned}
& =\sin 17^{\circ} 42^{\prime} 34^{\prime \prime} / \cos -6^{\circ} 59^{\prime} 4.98^{\prime \prime} \\
& =17^{\circ} 50^{\prime} 47^{\prime \prime}
\end{aligned}
$$

Al Fadl Bainahuma (FB)

$\mathrm{FB} \quad=$ SMQ-SMS

$$
\begin{aligned}
& =17^{\circ} 50^{\prime} 47^{\prime \prime}-21^{\circ} 22^{\prime} 33^{\prime \prime} \\
& =-3^{\circ} 31^{\prime} 45^{\prime \prime}
\end{aligned}
$$

\section{SIMPULAN}

Berdasarkan hasil kajian pembahasan di atas menunjukkan bahwa akhir Sya'ban 1438 H dengan markaz Menara al Husna Masjid Agung Jawa Tengah dengan menggunakan metode hisab kitab al Khulashah al Wafiyah adalah sebagai berikut:

Umur Bulan = 14 Jam 45 Menit

Tinggi Hilal $\quad=9^{\circ} 45^{\prime} 31^{\prime \prime}$

Cahaya Hilal $\quad=0.66 \%$

Azimuth Matahari $=21^{\circ} 22^{\prime} 33^{\prime \prime}(\mathrm{BU})$

Azimuth Bulan $\quad=17^{\circ} 50^{\prime} 47^{\prime \prime}$ (BU)

Beda Azimuth $\mathrm{I}=-2^{\circ} 0^{\prime} 32^{\prime \prime}$ (hilal di selatan matahari)

Beda Azimuth II $=-3^{\circ} 31^{\prime} 45^{\prime \prime}$ (hilal di selatan matahari)

Berdasarkan hasil hisab akhir Sya'ban $1438 \mathrm{H}$ di atas, yang berkaitan dengan umur bulan yang telah mencapai 14 jam 45 menit, tinggi bulan hakiki mencapai $9^{\circ} 45^{\prime} 31^{\prime \prime}$. Hal ini telah memenuhi syarat keriteria imkan rukyah baik keriteria Turki, MABIMS, maupun Cisarua untuk menerima hasil laporan rukyah, sehingga menurut hisab yang menggunakan kriteria imkan rukyah, 1 Ramadhan $1438 \mathrm{H}$ jatuh pada hari Sabtu Pahing, 27 Mei 2017 H. Namun demikian kepastian untuk ketetapan 1 Ramadhan $1438 \mathrm{H}$ hendaknya tetap menunggu hasil sidang itsbat dari Pemerintah RI yang akan dipimpin langsung oleh Mentri Agama RI hari Jum'at Legi, 26 Mei 2017 M selesai shalat maghrib di Jakarta. 


\title{
DAFTAR PUSTAKA
}

\section{Buku-buku}

Khazin, Muhyiddin, Kamus Ilmu Falak, yogyakarta: Buana Pustaka, 2005.

Azhari, Susiknan, Ensiklopedi Hisab Rukyat, Yogyakarta: Pustaka Pelajar, 2005.

Ghozali MF, Ahmad, al Dur al Aniq, Sampang: PP. Al Mubarok Lanbulan, 2013.

Izzuddin, Ahmad, Ilmu Falak Praktis: Teori dan Praktik, Yogyakarta: Buana Pustaka, 2007.

Ahmad Izzuddin, Ilmu Falak Praktis (Metode Hisab-Rukyat Praktis dan Solusi Permasalahannya), Semarang: Pustaka Rizki Putra, 2010

Umar Jaelani, Zubair, al Khulashoh al Wafiyah, Kudus: Menara Kudus, tt.

Hasna Tuddar Putri, Hisab Urfi Syekh Abbas Kutakarang: Kajian Etnoastronomi dalam Penentuan Awal Bulan Hijriah, Media Syari'ah, Vol 21, No 1 (2019), h. 52-72

Nihayatur Rohmah, Ijtimak Sebagai Prasarat Pergantian Bulan Baru

Dalam Kalender Hijriyah (Studi Analisis Ijtimak Awal Bulan Syawwal 1441h), Al-Mikraj Jurnal Studi Islam dan Humaniora, Vol 1 No 1 (2020),

\section{Makalah}

Makalah KH. Slamet Hambali, Hisab Khulashah al Wafiyah, 2017.

\section{Internet}

www.anizaida89.blogspot.co.id

www.fahmialinh.wordpress.com

www.generasisalaf.wordpress.com

www.ifanmedalem.blogspot.co.id

\author{
Alat \\ GPS \\ Google Earth
}

